\author{
RESEARCH PAPER
}

\title{
Economics of production of capsicum in Akola district
}

\author{
K.S. DAUNDKAR AND S.K. BAIRAGI
}

Received : 17.09.2014; Revised : 28.02.2015; Accepted : 15.03 .2015

\begin{abstract}
Chilli (Capscicum annuum L.) is most widely used and universal spice of India. The study was conducted in Akola district in greenhouse and open condition. Total 120 farmers were selected randomly as sample size. Economic analysis of data indicated that cost $\mathrm{C}$ at overall level was found to Rs. 1,25,260. Net returns over cost C was Rs. 2,73,388 and input-output ratio at cost C was 3.11.

KEY WORDS : Spice, Chilli, Cost of cultivation, Economics of production

How to cite this paper : Daundkar, K.S. and Bairagi, S.K. (2015). Economics of production of capsicum in Akola district. Internat. J. Com. \& Bus. Manage, 8(1) : 81-83.
\end{abstract}

